\title{
Antimicrobial effect of two endodontic medicaments with different exposure times, and the morphologic alterations caused to Enterococcus faecalis
}

\author{
Efeito antimicrobiano de dois medicamentos endodônticos com \\ diferentes exposições, e as alterações morfológicas causadas a \\ Enterococcus faecalis
}

\begin{abstract}
Purpose: The aim of this study was to verify the antimicrobial effect of calcium hydroxide and iodoform on Enterococcus faecalis with different exposure times evaluating the bacterial morphologic alterations.

Methods: The antibacterial action was investigated in culture broth after zero, seven, fourteen and twenty-one days. Five $\mathrm{mL}$ samples were analyzed morphologically on the seventh day by transmission electron microscopy. The data of the antibacterial test were analyzed by Fisher's exact test.

Results: The results revealed that between the seventh and fourteenth day, there was a decrease in bacterial growth with both medicaments $(P=0.098)$, where they were eliminated between the fourteenth and twenty-first day. Transmission electronic microscopy showed alterations in the morphologic structures.

Conclusion: It concluded that both medicaments kill Enterococcus faecalis, with an exposure time of 7 to 14 days, where no cell viability is seen after this period due to irreversible alterations in bacterial cell morphology.
\end{abstract}

Key words: Calcium hydroxide; Enterococcus faecalis; iodoform

\section{Resumo}

Objetivo: $O$ presente estudo verificou o efeito antibacteriano do hidróxido de cálcio e do iodofórmio em Enterococcus faecalis com diferentes tempos de exposição, avaliando as alterações morfológicas bacteriana.

Métodos: A ação antibacteriana foi investigada através de caldo de cultura após zero, sete, 14 e 21 dias, e assim, $5 \mathrm{~mL}$ das amostras do sétimo dia foram analisadas morfologicamente por microscopia eletrônica de transmissão. Os dados da ação antibacteriana em caldo foram analisados pelo teste Exato de Fisher.

Resultados: Os resultados revelaram que entre o $7^{\circ}$ e o $14^{\circ}$ dia houve diminuição do crescimento bacteriano com ambos os medicamentos $(P=0,098)$, onde a eliminação bacteriana ocorreu entre $\circ 14^{\circ}$ e $21^{\circ}$ dia. A microscopia eletrônica de transmissão apresentou alterações na estutura morfolófica bacteriana.

Conclusão: Pode-se concluir que ambos os medicamentos destroem o Enterococcus faecalis com tempo de exposição de 7 a 14 dias, onde a viabilidade celular não é observada após este período devido alterações irreversíveis na morfologia celular bacteriana.

Palavras-chave: Hidróxido de cálcio; Enterococcus faecalis; iodofórmio

\author{
Manoel Eduardo de Lima Machado ${ }^{\circ}$ \\ Guilherme Henrique Rosa Martins b \\ Karine Carreira ${ }^{c}$ \\ Karina Tramontina Peixotoc \\ Cleber Keiti Nabeshima ${ }^{b}$ \\ Ana Cristina Gales d
}

a Department of Restorative Dentistry, School of Dentistry, University of São Paulo, São Paulo, SP, Brazil

b Post-Graduate Program, Department of Restorative Dentistry, School of Dentistry, University of São Paulo, São Paulo, SP, Brazil

c Private Practice, São Paulo, SP, Brazil

d Department of Infectology, Federal University of São Paulo, São Paulo, SP, Brazil

Correspondence:

Guilherme Henrique Rosa Martins

Av. President Wilson, 1473 - cj. 15 - Centro

São Vicente, SP - Brazil

$11320-975$

E-mail:guimart@uol.com.br

Received: June 12, 2011

Accepted: October 16, 2011

Conflict of Interests: The authors state that there are no financial and personal conflicts of interest that could have inappropriately influenced their work.

Copyright: (c) 2011 Machado et al.; licensee EDIPUCRS. This is an Open Access article distributed under the terms of the Creative Commons AttributionNoncommercial-No Derivative Works 3.0 Unported License. 


\section{Introduction}

Persisting microorganisms in the root canal system is considered the main reason for the failure of endodontic treatment. Such fact is associated with factors related to the anatomic complexity of the root canal system, which imposes limitations on treatment since the mechanical action of endodontic instruments cannot reach certain canal walls (1). Thus, microorganisms can find favorable conditions for survival, releasing byproducts that impede the process of apical repair (2).

Among the microorganisms present in this polymicrobial infection, Enterococcus faecalis is the focus of many studies on this subject. It is a facultative Gram-positive bacterium that is found in asymptomatic chronic periapical lesions and that is associated with radiolucent images (3-6); it can survive for long periods in nutrient-poor areas (7); it adheres to collagenous tissues (8), and it survives in high-alkaline environments (9), allowing its survival after the disinfection of the canal (10).

Thus, intracanal antiseptics are indicated because of their ability to diffuse through the root canal system to kill the residual microorganisms in these regions after instrumentation of the root canal (1). Among these agents, calcium hydroxide is commonly used, and iodoform can be an alternative medicament.

Calcium hydroxide is a root canal dressing that is widely used; it releases hydroxide ions, causing an increase in the $\mathrm{pH}$ of the medium, which is unfavorable for bacterial growth (11). Though some works showed its antibacterial action against Enterococcus faecalis $(12,13)$.

The evaluation of the antibacterial efficacy of three calcium hydroxide formulations against Enterococcus faecalis on dentinal tubule infection showed better results when the calcium hydroxide was mixed with iodoform, and calcium hydroxide alone resulted in significantly higher numbers of Enterococcus faecalis (14).

Iodoform is a halogenated organic compound with a yellow color and characteristic odor, and it is widely utilized as an antiseptic with good results $(1,15)$, where it helps in tissue repair by potentiating the immune response (16). It shows diffusibility through dentin and cement (17). However, there is a lack of scientific evidence explaining its good clinical performance, mainly with regard to its antibacterial action.

Thus, the objective of this study was to determine the antimicrobial effect of calcium hydroxide and iodoform on Enterococcus faecalis using different exposure times and to evaluate the associated morphologic alterations using transmission electron microscopy (TEM).

\section{Materials and Methods}

A bacterial strain of Enterococcus faecalis (ATCC 29212) (Special Laboratory of Clinic Microbiology, Federal University of São Paulo, UNIFESP, São Paulo, Brazil) was grown on Miller-Hinton nutrient agar plates (Difco, Le Pont de Claix, France) for 24 h at $37^{\circ} \mathrm{C}$.
Calcium hydroxide $\left(\mathrm{Ca}(\mathrm{OH})_{2}\right)$ (Fórmula \& Ação, São Paulo, Brazil) and iodoform $\left(\mathrm{CHI}_{3}\right)$ (Fórmula \& Ação, São Paulo, Brazil) were each placed in a Falcon tube to be added to and diluted in $10 \mathrm{~mL}$ sterile glycerol for the sensitivity test, at a concentration of $64 \mathrm{mg} \mathrm{mL}^{-1}$.

Two 50-ml Falcon tubes containing $18 \mathrm{~mL}$ TSB (Tryptic Soy Broth, Difco, Le Pont de Claix, France) were labeled according to the following two groups:

- Group 1-2 mL of previously prepared calcium hydroxide solution were added;

- Group 2-2 mL of previously prepared iodoform were added;

After homogenization by vortexing, bacteria were added to the tubes with antiseptics to be tested and the control $(n=3)$ to obtain a bacterial suspension adjusted to $\geq 10^{9} \mathrm{CFU} / \mathrm{mL}$ according to McFarland scale, determined by turbidimetry. The control group consisted of a bacterial suspension also adjusted to $\geq 10^{9} \mathrm{CFU} / \mathrm{mL}$, and a tube with $18 \mathrm{~mL}$ TSB only to prove the sterility. All samples were performed in triplicate. At this time, a serial dilution was done with three drops of $20 \mu \mathrm{L}$ of all the samples were removed and added to nutrient agar plates to test for viability. The plates were placed in a microbiology incubator at $37^{\circ} \mathrm{C}$ for $24 \mathrm{~h}$, and were then examined for $\mathrm{CFU}$, which were converted in relation to initial volume of each sample to determine cell viability.

At 7, 14 and 21 days the same test was done, without the addition of nutrients and performed on three different occasions to confirm and validate the data obtained (reproducibility test),

The data obtained were presented as the logarithmic mean and standard deviation. Statistical analysis was carried out using Fisher's exact test, evaluating the differences between the exposure times of the groups tested and the group control, with the level of significance set at $5 \%$.

In TEM analysis, $5 \mathrm{~mL}$ of sample were removed from the tubes, and fixed in a solution of $2.5 \%$ glutaraldehyde and $2 \%$ formaldehyde. Sections of 70 to $90 \mathrm{~nm}$ thickness were contrasted in a saturated aqueous solution of uranyl acetate and lead citrate. Electron micrographs were obtained with a transmission electron microscope at $80 \mathrm{kV}$.

\section{Results}

Antibacterial test

There was a decrease in the number of colonies formed by $E$. faecalis dependent on the exposure time relative to the positive control group (Fig. 1). The two dressings tested showed similar results $(P=1)$, where there was a sudden decline in the formation of bacterial colonies between 7 and 14 days exposure $(P=0.098)$ and no CFU between 14 and 21 days $(P=1)$, in relation to the control group. With respect to the TSB control group, no sample of culture medium contaminated during this experiment. This result was identical for the three repetitions $(P=1)$. The results are shown in Table 1. 


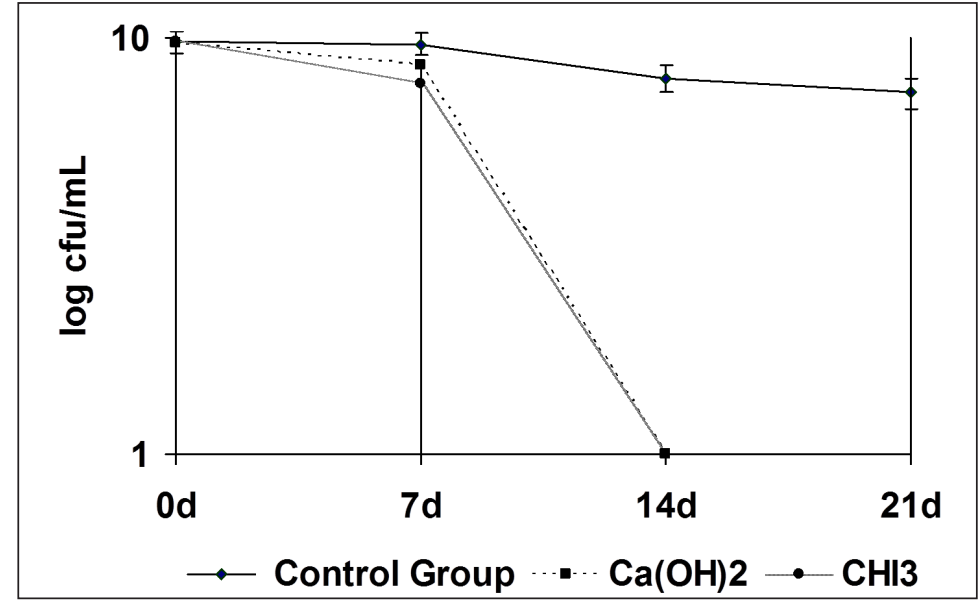

Fig. 1. Effect of antibacterial root canal dressing on Enterococcus faecalis in mean $\log 10 \pm$ SE for different exposure times.

Table 1. Mean values in $\log 10$ number and standard deviation of the groups tested for different exposure times.

\begin{tabular}{lcccc}
\hline & $\begin{array}{c}\text { lodoformium } \\
\mathrm{CHI}_{3}\end{array}$ & $\begin{array}{c}\text { Calcium Hydroxide } \\
\mathrm{Ca}(\mathrm{OH})_{2}\end{array}$ & Control Group & $\begin{array}{c}\text { TSB } \\
\text { Control Group }\end{array}$ \\
\hline Initial & $9.88 \pm 0.19$ & $9.69 \pm 0.53$ & $9.76 \pm 0.13$ & - \\
7 days & $8.99 \pm 1.43$ & $9.19 \pm 0.46$ & $9.65 \pm 0.15$ & - \\
14 days & $1^{*} \pm 0$ & $1^{*} \pm 0$ & $8.58 \pm 0.08$ & - \\
21 days & $1^{*} \pm 0$ & $1^{*} \pm 0$ & $7.37 \pm 0.11$ & - \\
\hline
\end{tabular}

${ }^{*} \log 100=1$

TEM

Cells were examined by TEM only on the 7th day, because at the start of the experiment, no alteration in bacterial structure was observed and because at fourteen and twentyone days there was no cell viability in the treatment groups.

E. faecalis cells in the control group after 7 days incubation in TSB culture medium, showed an intact cell wall that was delimited and intact, and contained cytoplasmic protein material distributed in a uniform and organized manner (Fig. 2A).

In the presence of iodoform, the bacterial cells demonstrated disorganized and irregular cytoplasmic material with the formation of vesicles, and when adhered to the cell wall extracellularly, there appeared to be an alteration in the integrity of the wall. In some cells, the externalization of cytoplasmic material could be seen by way of vesicles and rupture of the cell membrane (Fig. 2B).

Calcium hydroxide treatment caused cytoplasmic alterations with the presence of denser areas and clear formations of vesicles. There were extracellular vesicles communicating with the bacterial wall, showing alteration of this region and externalization of cytoplasmic material. Some bacterial cells appeared to be undergoing bacteriolysis (Fig. 2C).

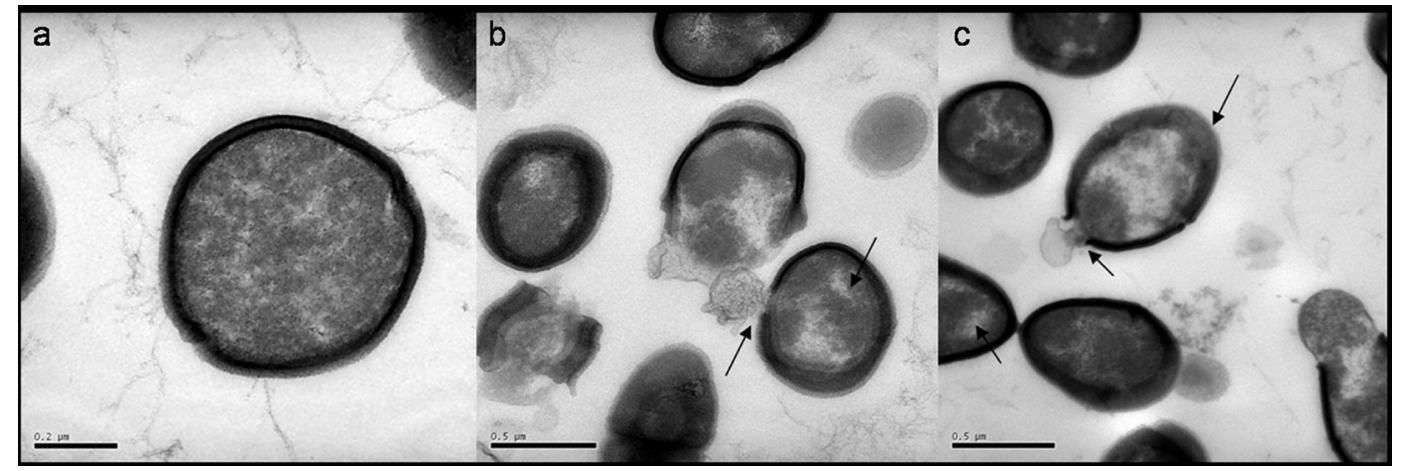

Fig. 2. Transmission electron micrographs of E. faecalis (20.000x). (a) Control group. (b) lodoform group: a disorganized cytoplasmic material with vesicle formations protruding from the cell and damaging the membrane (black arrows). (c) Calcium hydroxide group: clear cytoplasmic zones, black spots and vesicle formation and damage to the membrane, with a few vesicles blebbing out from the outer wall (black arrows). 


\section{Discussion}

The disinfection of the root canal system by instrumentation, irrigants and endodontic medicaments in teeth that need endodontic treatment is important for the process of periapical healing $(1,2)$. According to the literature, one of the microorganisms causing these endodontic failures is Enterococcus faecalis $(3,4)$, because it is able to survive in poor-nutrient environments (7). Therefore, this bacterium was chosen for this test, and it has often been used in endodontic studies.

When the medicament is exposed to the outer cell wall, irreversible morphologic alterations can result leading to lysis of the microorganism, with release of its DNA into the medium in which it occurs (9). The study by TEM is essential to be able to observe the alterations that antiseptics cause in microorganisms, in order to better understands its mechanism of action (18). In addition, studies in plankton media can evaluate the antimicrobial action of antiseptics against particular pathogens $(9,19-21)$. In this study, the antimicrobial test was performed in plankton medium to observe morphologic alterations by TEM, where the bacteria were exposed to the test agents for up to 21 days, without the addition of culture medium and after being determined in a pilot test. In this manner, CFU assays were also carried out at exposure times of $0,7,14$ and 21 days for antibacterial evaluation of the agents $(12,14)$, simulating clinical times during endodontic treatment. The combination of different methods made the studies clear.

Calcium hydroxide was employed in this study, as it is an antiseptic utilized worldwide. Iodoform, as well, is a substance that has been forgotten with the passing of time with regard to basic research (1), despite its clinical success $(14,15,19)$. The United States Department of Heath, Education and Welfare did not show carcinogenic effects (22), and the Food and Drugs Administration (FDA) approved its topical and intra-dental use (23).

With regard to the exposure times, the results demonstrated bactericidal action between 7 and 14 days of exposure, a period during which the antiseptic impedes bacterial growth. TEM findings were similar to those by Castillo et al. (18), who observed irreversible alterations such as cytoplasmic alterations, formation of internal vesicles and external ones adhered to the cell wall, and rupture of the cell wall, in a study with chlorhexidine. These results were obtained on the seventh day, because at time zero there were no significant changes observed, and because on the $14^{\text {th }}$ and $21^{\text {st }}$ day there were no viable bacteria.

This study showed that both test agents are bactericidal and that they need to remain as an antiseptic agent for seven to fourteen days $(12,14)$; in this period the agent spreads throughout the root canal system attacking microorganisms that survive the mechanical and chemical disinfection of the root canal (7).

Calcium hydroxide acts through $\mathrm{pH}$ change, even though our results showed that it can act on alkali-resistant bacteria, but it needs direct contact with the bacterial cell wall. Killing of bacteria by calcium hydroxide will depend on the availability of hydroxyl ions in solution, because hydroxyl ions induce lipid peroxidation, resulting in the destruction of phospholipids, structural components of the cell membrane (19). Iodoform seems to work through a similar mechanism, with a slow and continuous release of iodine that acts on cellular lipids (16).

Despite the particularities of the mechanism of action of each medicament, both acts directly on the bacterial cell wall, but further studies are needed since the local conditions such as the presence of organic and inorganic substances are factors that can influence the antibacterial effect of medicaments $(20,21)$.

\section{Conclusions}

Thus, based on the methods used and the analysis of the results, both antiseptics tested demonstrated an antimicrobial action against $E$. faecalis after 7 to 14 days of exposure, where morphologic alterations occurred in the bacteria.

\section{References} 1. Machado MEL, Palotta RC, Souza ADS. Substâncias medicamentosas auxiliares da
desinfecção - Medicação intra e extracanal. In: Machado MEL. Endodontia da biologia à técnica. São Paulo: Editora Santos; 2007.p.299-320.

2. Haapasalo M, Udnæs T, Endal U. Persistent, recurrent, and acquired infection of the root canal system post-treatment. Endod Topics 2003;6:29-56.

3. Siren EK, Haapasalo M, Ranta K, Salmi P, Kerosuo ENJ. Microbiological findings and clinical treatment procedures in endodontic cases selected for microbiological investigation. Int Endod J 1997;30:91-5.

4. Peciuliene $\mathrm{V}$, Reynaud AH, Balciuniene I, Haapasalo M. Isolation of yeasts and enteric in root-filled teeth with chronic apical periodontitis. Int Endod J 2001 ;34:429-34.

5. Pinheiro ET, Gomes BPFA, Ferraz CCR, Sousa EL, Teixeira FB, Souza-Filho FJ. Microorganisms from canals of root-filled teeth with periapical lesions. Int Endod J 2003:36, 1-1 1.

6. Rôças IN, Siqueira Júnior JF, Santos KRN. Association of Enterococcus faecalis with different forms of periradicular diseases. J Endod 2004;30:315-20.

7. Sedgley CM, Lennan SL, Appelbe OK. Survival of Enterococcus faecalis in root canals ex vivo. Int Endod J 2005;38:735-42. 
8. Kayaoglu G, Erten $\mathrm{H}$, Ørstavik D. Growth at high $\mathrm{pH}$ increases Enterococcus faecalis adhesion to collagen. Int Endod J 2005;38:389-96.

9. Portenier I, Waltimo T, Ørstavik D, Haapasalo M. The susceptibility of starved, stationary phase and growing cells of Enterococcus faecalis to endodontic medicaments. J Endod 2005;31:380-6.

10. Portenier I, Waltimo TMT, Haapasalo M. Enterococcus faecalis - the root canal survivor and 'star' in post-treatment disease. Endod Topics 2003;6:135-59.

11. Safavi KE, Nakayama TA. Influence of mixing vehicle on dissociation of calcium hydroxide in solution. J Endod 2000;26:649-51

12. Lynne RE, Liewehr FR, West LA, Patton WR, Buxton TB, McPherson JC. In vitro antimicrobial activity of various medication preparations on E.faecalis in root canal dentine. J Endod 2003;29:187-90.

13. Lui JN, Sae-Lim V, Song KP, Chen NN. In vitro antimicrobial effect of chlorhexidineimpregnated gutta percha points on Enterococcus faecalis. Int Endod J 2004;37:10513.

14. Cwikla SJ, Bélanger M, Giguère S, Progulske-Fox A, Vertucci FJ. Dentinal tubule disinfection using three calcium hydroxide formulations. J Endod 2005;31:50-2.

15. Pallotta RC, Ribeiro MS, Machado MEL. Determination of the minimum inhibitory concentration of four medicaments used as intracanal medication. Aust Endod J 2007;33:107-11.

16. Pallotta RC, Machado MEL, Reis NS, Martins GHR, Nabeshima CK. Tissue inflammatory response to implantation of calcium hydroxide and iodoform in the back of rats. Rev Odonto Ciênc 2010;25:59-64.

17. Franco ABG, Machado MEL, Nabeshima CK. Qualitative evaluation of iodoform diffusibility through dentin and cement. Res J Biol Sci 2010;5:264-8.

18. Castillo JA, Clapés P, Infante MR, Comas J, Manresa A. Comparative study of the antimicrobial activity of bis (Na-caproy 1-L-arginine)-1,3-propanediamine dihydrochloride and chlorhexidine dihydrochloride against Staphylococcus aureus and Escherichia coli. J Antimicr Chemother 2006;57:691-8.

19. Siqueira Júnior JF, Lopes HP. Mechanisms of antimicrobial activity of calcium hydroxide: a critical review. Int Endod J 1999;32:361-9.

20. Haapasalo HK, Sirén EK, Waltimo TMT, Ørstavik D, Haapasalo MP. Inactivation of local root canal medicaments by dentine: an in vitro study. Int Endod J 2000;33:126-31.

21. Portenier I, Haapasalo H, Rye A, Waltimo T, Ørstavik D, Haapasalo M. Inactivation of root canal medicaments by dentine, hydroxylapatite and bovine serum albumin. Int Endod J 2001;34:184-8.

22. Bioassay of iodoform for possible carcinogenicity (CAS No. 75-47-8). Natl Cancer Inst Carcinog Tech Rep Ser 1978;1 10-7.

23. Food and Drug Administration. lodoform [cited on 2011 January 20]. Available at: http:// www.fda.gov/ohrms/DOCKETS/ac/98/briefingbook/1998-3454B1_02_30-BDL17.pdf 